\title{
Percurso para a utopia: o Eldorado de Milton Hatoum
}

Route for utopia: Milton Hatoum's Eldorado

\author{
Jefferson Agostini Mello*
}

\begin{abstract}
RESUMO
A proposta deste ensaio é a de apreender o percurso estético-literário de Milton Hatoum, que flutua entre uma perspectiva mais local e outra mais global. Trata-se de demonstrar que Hatoum estreia com um romance de ambição universal, escreve na sequência dois romances em diálogo mais evidente com o local e, em uma espécie de volta ao começo, publica em 2008 uma novela em que convivem lirismo, universalismo e utopia.

Palavras-chave: Milton Hatoum; ficção brasileira contemporânea; local; universal.
\end{abstract}

\begin{abstract}
The goal of this essay is to achieve a deeper understanding of Milton Hatoum's literary and aesthetical course, which shifts from global to local perspectives. It's demonstrated that Hatoum debuts with a novel of universal ambition, then writes two novels dealing mostly with local themes, and, in 2008, as a return to the starting publishes a novel in which lyricism, universalism and utopia coexist.
\end{abstract}

Keywords: Milton Hatoum; Brazilian contemporary fiction; local; universal. 
1. O escritor brasileiro Milton Hatoum, desde a sua estreia literária em 1989, com o romance Relato de um certo Oriente, tem escrito ficções com grande viabilidade para a consagração, em um diálogo orgânico com um mundo de referências e estilos e com pouca ousadia estética, o que para alguns críticos constitui marca positiva de sua obra. Olhando mais para trás do que para frente, o autor lança mão de materiais acumulados para construir histórias em que se mesclam aspectos da realidade social, da tradição literária brasileira e ocidental, e dos mitos da Amazônia. Surgem assim, misturados em seus romances, ecos de José de Alencar, de Machado de Assis, de Flaubert, de José Lins do Rego, de Graciliano Ramos, das tragédias gregas, da Bíblia, além da história factual da ditadura militar brasileira e dos ciclos econômicos devastadores para o país.

Com efeito, a relação da obra de Hatoum com a sociedade brasileira fica mais evidente a partir do seu segundo romance, Dois irmãos (2000), e segue com mais força em Cinzas do Norte (2005). Na novela Órfãos do Eldorado, de 2008, o mito amazônico da busca de uma cidade submersa ${ }^{1}$ ganha também tintas utópicas. A vinculação da obra à realidade social brasileira ainda está presente, porém, atenuada. Em comparação com os dois escritos anteriores, há nessa novela elementos do poético, que introduzem o devaneio e a imaginação, e que minam o distanciamento característico da prosa mais realista, talvez porque Hatoum opte, neste caso, por um narrador senil, decadente, mas assomado pelo desejo, que passa a vida recordando um amor de juventude. Igualmente, no seu quarto livro, parece diminuir a preocupação com o registro dos acontecimentos e com a fidedignidade das fontes - como é o caso do narrador-testemunha de Cinzas do Norte, que busca o tempo todo trazer para o leitor a origem das informações - mesmo que Órfãos do Eldorado tenha como mote, como se verá, a narrativa oral. Portanto, não seria demais sugerir que a novela de 2008 retoma trilhas do primeiro romance, com a maior presença do traço lírico, ${ }^{2}$ e busca se afastar, embora não a descarte, da mistura de arte e política - própria da escrita de cunho mais realista.

A proposta deste ensaio é a de, por meio da análise de parte da fortuna crítica da obra de Hatoum, e seguindo com a leitura de alguns

${ }^{1} \mathrm{O}$ livro foi escrito para a coleção Mitos, da Canongate Books.

${ }^{2}$ De acordo com Emil Staiger, não se pode falar em pureza dos gêneros - "Uma poesia lírica [...], justamente porque se trata de um poema, não pode ser exclusivamente lírica. Participa em diversos graus e modos de todos os gêneros, e apenas a primazia do lírico nos autoriza chamar os versos líricos" - e o lírico, cujos traços se podem perceber no romance de Milton Hatoum, seria para Staiger o gênero da recordação: "[...] o narrador torna presente fatos passados. O poeta lírico nem torna presente algo passado, nem também o que acontece agora. Ambos estão igualmente próximos dele; mais próximos que qualquer presente. Ele se dilui aí, quer dizer ele 'recorda'. 'Recordar' deve ser o termo para a falta de distância entre sujeito e objeto, para o um-no-outro lírico". (STAIGER, 1975, p. 59). 
aspectos de Cinzas do Norte e Órfãos do Eldorado, apreender um percurso estético-literário itinerante, entre uma perspectiva mais particular e outra mais universal. Dito de outro modo, trata-se de demonstrar que Hatoum, quem sabe até provocado e/ou impulsionado pelos comentários sobre a sua obra, estreia com um romance de ambição universal e traços líricos, escreve na sequência dois romances permeados por traços dramáticos, em diálogo mais evidente com questões locais e brasileiras, e, em uma espécie de volta ao começo, publica em 2008 uma novela em que convivem utopia, lirismo e universalismo.

2. O romance de estreia de Milton Hatoum, Relato de um certo Oriente (1989), foi interpretado pela crítica de primeira hora como um trabalho de linguagem e de rememoração subjetiva. Esta observou nele, igualmente, ressonâncias que vão desde As mil e uma noites até a obra de autores como Faulkner e Virginia Woolf, sem fazer menções a qualquer tipo de fatura mais realista, embora motivos amazônicos e da imigração libanesa fossem eventualmente apontados.

Assim, na própria orelha do romance, Davi Arrigucci Jr. (1989) frisou não apenas seu aspecto lírico, mas também a sua formulação como um universo próprio, com sutis referências ao espaço manauara:

O romance é aqui uma arquitetura imaginária: a arte de reconstruir, no lugar das lembranças e vãos do esquecimento, a casa que se foi. Uma casa, um mundo. Um mundo até certo ponto único, exótico e enigmático em sua estranha poesia, mas capaz de se impor ao leitor com alto poder de convicção. (ARRIGUCCI JR., 1989).

Como se nota, justamente por ser uma arquitetura imaginária, e que tem alto poder de convicção, o Relato de um certo Oriente, na apreciação do crítico, parece não valer tanto por seu caráter mimético, de representação de algo que está para além ou para aquém dele, muito pelo contrário. Pode-se inferir que o traço lírico, juntamente com o "raro senso plástico", nas palavras de Arrigucci Jr., atenuariam a exatidão narrativa, criando perspectivas borradas e impressionistas a impedir a referência direta à realidade e a mimetizar antes de tudo o trabalho da memória, que é efeito, sobretudo, da imaginação.

Não é muito diferente a apreciação de Alfredo Bosi do romance, que no seu clássico História concisa da literatura brasileira prestigia o autor ainda estreante. Seu foco, porém, é o estilo da escrita de Hatoum: 
A escrita apurada de um estreante como Milton Hatoum parece indicar (como fizeram, nos anos 70, Raduan Nassar com Lavoura Arcaica e Carlos \& Carlos Sussekind com Armadilha para Lamartine) que um certo ideal de prosa narrativa, refletida e compassada, que vem de Graciliano e chegou a Osman Lins, não é forçosamente fruto de um passado estético irreversível. Esse padrão resiste em meio aos cacos do mosaico pós-moderno e significa a vitalidade de um gosto literário sóbrio que não renuncia à mediação da sintaxe bem composta e do léxico preciso, sejam quais forem os graus de complexidade da sua mensagem. A ideia de arte como trabalho baqueou, mas ainda não morreu. (BOSI, 2003, p. 437).

Mais do que para Arrigucci Jr., que se detém principalmente na arquitetura da obra de Hatoum, para Bosi, a arte literária do escritor então iniciante seria também uma espécie de reserva moral da boa escrita em uma cena tomada pelo simulacro pós-moderno. Expressões como sintaxe bem composta e léxico preciso remeteriam não só a uma perenidade do que ele considera boa literatura em tempos sombrios, estilo perceptível também em outros escritores brasileiros, mas, ao mesmo tempo, a Gustave Flaubert, um dos modelos literários de Hatoum, que Bosi não nomina, mas que, como se sabe, escrevia em busca da palavra justa ("escrita apurada”).

Mas se os dois críticos de São Paulo não farão reservas ao Relato de um certo Oriente, Flora Süssekind, do Rio de Janeiro, escrevendo igualmente logo após a publicação do romance, criticará certo didatismo na condução da narrativa, provavelmente porque esperava algo mais ousado do seu autor. Assim, o que para aqueles críticos seriam traços positivos da obra (organicidade, concentração, sobriedade, boa escrita), para ela diminuiriam o seu poder, uma vez que, ao invés de uma justaposição de monólogos, o romance apresenta toda a história concentrada na perspectiva de um único narrador. Mesmo assim, a autora não deixa de notar parentescos da prosa de Hatoum com As ondas, de Virginia Woolf, ou com O som e a fúria, de Faulkner, e acaba, ao final, elogiando não só a exigência do escritor consigo mesmo - em meio a, segundo ela, tantos romances de confissão e tantos retratos falhados de geração - como também as "raras analogias" com La Muerte y la Nina, de Onneti, e com A câmara clara, de Roland Barthes.

3. Não tendo apreciado a contenção narrativa do Relato de um certo Oriente, imagina-se que Süssekind, ao contrário de Bosi, bem mais propensa ao experimentalismo verbal, desaprovaria quase que inteiramente o romance seguinte de Hatoum, em que o traço lírico se atenua, surgindo então analogias com aspectos da nossa realidade, sobretudo com a lógica do favor, com a violência entranhada no mandonismo, com a ditadura militar, com a miséria social, etc. No plano das ressonâncias, há também menos 
espaço para obras literárias estrangeiras consagradas - apesar do paralelo com Domingas-Félicité, de Flaubert, lembrado pelo autor em mais de uma entrevista - do que para clássicos brasileiros, como, por exemplo, Esaú e Jacó de Machado de Assis. Ainda, fazem-se também presentes as referências a obras da nossa literatura que tematizam espaços decadentes - desde casas (A crônica da casa assassinada) até propriedades rurais (São Bernardo, Fogo morto) - essas também com seus agregados, tipo ideal brasileiro que é também o narrador do romance de Hatoum.

Não obstante, mesmo em Dois irmãos, outros críticos de peso aliás, não deixa de ser interessante notar a recepção atenta e de primeira hora, desses primeiros dois romances por críticos consagrados - como Luiz Costa Lima, Benedito Nunes e Leyla Perrone-Moisés farão o elogio da universalidade da narrativa, evitando associá-la demais a questões brasileiras, talvez porque a obra mesma se situe no meio do caminho, entre o particular e o geral, com um estilo que lembra a fórmula contraditória de Flaubert, a saber, o realismo artístico. ${ }^{3}$

Ao escrever sobre Dois irmãos (2000), Luiz Costa Lima (2000) pendeu, na sua avaliação, para o aspecto universal da obra, e, assim como Benedito Nunes, ${ }^{4}$ enfatizou a estruturação da obra a partir do mito, no caso, 0 do noivo cativo da mãe, que determinaria o destino de todos os personagens e, consequentemente, o espaço desregrado. Segundo ele, "a figura do 'noivo cativo' tem a força pregnante de um mito. Seu destino faz lembrar Dionisio destroçado. Um mito que concentra as coordenadas do mundo sem raízes".

Assim, Nael, o narrador, que busca refazer a sua história e descobrir qual dos dois irmãos gêmeos protagonistas é o seu pai, Yakub ou Omar, apenas "cumpre o seu recado". Nas palavras de Costa Lima, "não se entenda que escreve o documento da memória! Pensá-lo seria dar prova de não haver entendido nada. O mito do 'noivo cativo' é a viga que constrói o que os filhos da família haviam destruído, como parte de uma estrutura que desconheciam". Ou seja, para o crítico, a condição de um narrador com marcas de um agregado típico, que conta de uma posição limítrofe tanto a sua história quanto a dos outros, é fruto de algo maior, que estaria acima dele, importando menos a história brasileira internalizada no foco narrativo,

\footnotetext{
${ }^{3}$ Um dos únicos críticos de primeira hora a focar no narrador de Dois irmãos foi Luiz Augusto Fischer (2002), após uma síntese do enredo, encerra sua resenha dessa forma: "Mas o que dói mesmo é a história da família e a dureza da vida do mestiço filho da índia, que narra a história para entender seu lugar nesse mundo".

${ }^{4}$ Para Nunes (2006, p. 333), que vê em A pedra do reino, de Ariano Suassuna, Lavoura arcaica, de Raduan Nassar e Dois irmãos, de Hatoum, um "terceiro surto do mito no romance brasileiro", haveria o "comum estofo narrativo dos três citados romances - as popularescas histórias de cordel nordestinas do primeiro, a parábola bíblica do segundo e a tríplice linhagem, etnográfica, religiosa e literária do terceiro".
} 
que como se sabe, assim como o mito por ele evocado, é grande produtora de párias como Nael.

É verdade que, por outro lado, Costa Lima valorizou o espaço romanesco e a particularidade brasileira, com afirmações como esta: "erraria o leitor que visse na ambiência dos dois romances de Hatoum o mero lugar onde uma história humana se desenrola. O continente é aqui parte do conteúdo" (2000). Ou como esta, na revisão da resenha, em 2001, em que dá nome à estrutura que os gêmeos desconheciam: "capitalismo periférico, cumprido em uma área dentro dele marginal" (2002, p. 321). Frisaria ele, também, o parentesco do romance com narrativas de Faulkner ou García Márquez, "que tematizam a marginalidade da terra que as contém, terras a que se estendeu, sem propriamente a internalizar, a estrutura da sociedade pós-iluminista" (2001, p. 319).

E talvez por isso o crítico refutaria ao final qualquer pretensão da narrativa em ombrear com a literatura dos países desenvolvidos. A sua universalidade viria garantida apenas pela sua estruturação a partir do mito, o seu ponto alto, ou melhor, notável:

Aqui não se escreve sobre um romance que diminuiria nossa carência de ficção de qualidade. Dois Irmãos pertence a outros parâmetros. O mito que cria e fecunda configura um romance que supõe uma matéria social bem diversa da ficção de qualidade do primeiro mundo. A casa que se destrói conta de uma sociedade absolutamente sem amarras internas, onde repontam poucas ilhas, que se fazem e desfazem. Mas essa é a sua matéria sociológica. 0 realmente notável em Dois Irmãos é a solda da forma alcançada. Forma que se nutre de um núcleo mítico enquanto se metamorfoseia em romance. $O$ romance de um mundo flutuante, assediado tanto pela razão calculadora como por afetos desenfreados. (LIMA, 2002, p. 321-322).

Em leitura do mesmo romance, Leyla Perrone-Moisés pareceu, em primeira visada, mais atenta às marcas do particular, pois ao lado do aspecto universal de Dois irmãos, resgatando as categorias aristotélicas de reconhecimento e peripécia, assim como o tema dos gêmeos, ela não deixou de evocar questões amazonenses. O cômputo geral, entretanto, é o de que, "inevitavelmente atado à realidade amazônica, o livro de Hatoum, como todas as boas obras literárias, tem uma dimensão universal, por ser também, e sobretudo, um livro sobre a memória e o esquecimento, a vingança e o perdão" (2000), aspectos, sem dúvida, demasiadamente humanos e que ultrapassam quaisquer particularidades. Em todo o caso, Perrone-Moisés soube vincular o espaço amazônico à história contemporânea. De acordo com ela, 
Sem ceder a modismos superficiais, o romance de Hatoum é, em sua temática e em sua forma, muito atual. O livro tem muitas semelhanças com os de certos autores pós-coloniais indianos, sobretudo com $O$ Deus das pequenas coisas, de Arundhati Roy. Malgrado as diferenças históricas, os mundos retratados nesses romances acabam por assemelhar-se. São mundos arruinados pela colonização, desfigurados pela globalização, onde as casas familiares se esvaziam e desmoronam, deixando apenas, na memória, pequenos paraísos naturais. (PERRONE-MOISÉS, 2000, p. 7).

Ressalte-se na citação acima que, além do espaço amazônico, Perrone-Moisés articula a obra de Hatoum a outras representações contemporâneas do espaço mundial. Contudo, perguntaria o leitor atento, onde fica o Brasil nessa geografia? Para a autora, "a peculiaridade brasileira retratada no romance é a de reproduzir, invertida em latitude, a desigualdade Norte-Sul: calor e atraso econômico na Manaus de Omar, frio e desenvolvimento na São Paulo de Yakub" (2000). Em outras palavras, o microcosmo do romance representaria não as contradições brasileiras, mas, por espelhamento, aquelas da globalização, sendo São Paulo, no sul do Brasil, o equivalente à Europa e aos Estados Unidos, no norte do globo. No conjunto, em uma leitura que pautará por um bom tempo outras leituras de Dois irmãos, Perrone-Moisés promove Hatoum seja como um autor universal - no sentido de seu texto dizer de coisas gerais, a partir de temas e formas da literatura ocidental seja como um autor global, ao dialogar não apenas com autores de outras partes do mundo como também por tratar literariamente de problemas da realidade do planeta, como o faz o seu colega indiano. Diversas interpretações multiculturalistas e pós-colonialistas do romance tirarão partido dessa visão por assim dizer globalizante inaugurada por Perrone-Moisés, a despeito dela, como se sabe, tomar distância com relação a tais perspectivas. ${ }^{5}$

Foi provavelmente Tânia Pellegrini que, em ensaio alentado de 2004 (não se trata de uma resenha de jornal, mas de um texto para periódico

${ }^{5}$ Já em Altas literaturas, de 1998, Perrone-Moisés alertava: "No Brasil, sempre dividido entre a influência européia e a norte-americana, esta última está atualmente ganhando terreno. Embora se mantenham, em muitas universidades, os departamentos de teoria literária e os cursos de literaturas nacionais hegemônicas, o multiculturalismo, o pós-colonialismo, o sexismo e outras tendências voltadas para a particularidade aparecem como novos conteúdos de programas, de teses, ou como disciplinas optativas. Apesar de o estudo exclusivo de um tema, ou a adoção de um ponto de vista particular não contribuir muito para o conhecimento das obras literárias e só servir para reforçar ideologicamente aquele ponto de vista predeterminado, podemos considerar esses novos enfoques como acréscimos e aberturas. Mas o que já acontece nos Estados Unidos, onde os estudos particularistas tomam o lugar de estudos universalistas como a teoria literária e a estética, acusando-os de defender uma ideologia eurocêntrica, elitista e patriarcal, pode muito bem ocorrer aqui nos próximos anos e, nesse caso, a abertura ao anteriormente excluído acarretaria a exclusão curricular de grandes áreas do saber" (PERRONE-MOISÉS, 1998, p. 194). 
acadêmico), explorou o que o próprio Hatoum e seus críticos tentaram evitar, a saber, o seu vínculo com o particular e, mais especificamente, com a realidade brasileira e com a literatura brasileira regionalista, perceptível a seu ver tanto no Relato de um certo Oriente, quanto em Dois irmãos. Portanto, na contramão da crítica que via um Milton Hatoum universal e cosmopolita, ela interpretou a mistura do particular e do geral nos dois primeiros romances do autor como uma revisitação do regionalismo, a qual possibilitou que ele renovasse um gênero (sic) e uma perspectiva ainda necessários para o país. Aproveitando-se de alguns achados de Perrone-Moisés, tais como as categorias de reconhecimento e peripécia por esta detectadas em Dois irmãos, Pellegrini acredita que é principalmente ao multiculturalismo que a obra de Hatoum responde criticamente. Quer dizer, o regionalismo, assim como a tradição da literatura ocidental, já sedimentados, funcionariam como um escudo, prevenindo então contra as facilitações multiculturais:

[…] lançando mão das contribuições das matrizes literárias urbanas clássicas, modernas e contemporâneas, já incorporadas, e à sua luz revendo os conteúdos regionais, [o regionalismo de Hatoum] compõe um tecido rico no seu hibridismo, que conserva ainda vivas todas as suas fontes e é capaz de continuar transmitindo a herança delas recebida. É uma herança renovada que, todavia, ainda se identifica completamente com o passado, resgatando-lhe a identidade e impedindo sua transformação em "texto multicultural". (PELLEGRINI, 2004, p. 135).

4. Quanto a Cinzas do Norte, de 2005, dar ênfase a temas universais, mesmo articulando-os a particularidades e regionalismos, torna-se bem mais difícil, pois mesmo que o romance não deixe de sugerir o mito de Édipo, ou mesmo o do noivo cativo pela mãe, abordando, também, questões de arte (arte utilitária $\mathrm{X}$ arte política), tudo nele vem atravessado por especificidades sociais e políticas, que se impõem e parecem estruturá-lo do início ao fim.

Isso foi observado logo após a publicação do livro por Fabio de Souza Andrade que, em resenha curtíssima, captou bem tanto aspectos do estilo quanto da temática de Cinzas do Norte, vendo nele mais particularismos do que universalismos. Na esteira de Alfredo Bosi e Arrigucci Jr., o crítico também ressaltou como Hatoum se distancia de alguns cacoetes da literatura contemporânea (experimentalismo, oportunismo de mercado, naturalismo, em referência indireta à Cidade de Deus, de Paulo Lins), optando pela discrição e pelo foco narrativo concentrado na luta do pai contra o filho. Mesmo assim, Andrade chamou a atenção sobretudo para o modo como o autor, com técnica impecável, elabora uma representação do Brasil, via Amazônia: 
Na imensidão da floresta, o custo da construção dos impérios econômicos, recentes e mudando de mão em ritmo vertiginoso, inclui uma relação de promíscua cordialidade, mediada pela violência e pela exploração, das elites com os caboclos ribeirinhos. No romance, em terra de lei recente e em tempos de exceção, a submissão pela força ou cooptação pelo favor quebram a fibra moral de alto a baixo, não deixando espaço para simpatias maniqueístas e dissolvendo as boas intenções. (ANDRADE, 2005, p. 2).

No argumento do crítico, percebe-se o destaque a um conjunto cultural, político e histórico bem brasileiro: a lucratividade a todo o custo, atravessada pela prática do favorecimento, em plena ditadura militar. De modo que se poderia inferir que o núcleo familiar rico do romance, juntamente com as personagens que vivem nas suas bordas, metaforizam um período histórico particular, os anos 60 e 70, que se liga igualmente ao passado (a prática do favor, a dependência econômica) e reverbera no presente.

Não é meu interesse discutir o valor da mudança estética de Hatoum, se ela é boa ou ruim. Gostaria apenas de indicar que é para uma escrita voltada para uma temática mais específica e para um forma mais mimética que o romance tende. Com efeito, trata-se sobretudo de uma obra de cunho realista, embora o faça com sobriedade estilística, qualidade que permanece no autor e faz com que evite supostos exageros, que o levariam às tintas carregadas do naturalismo. $\mathrm{E}$, em uma espécie de leitura retrospectiva, não seria demais sugerir que a relação de promíscua cordialidade em Cinzas do Norte já aparece em Dois irmãos, nas situações de violência física e simbólica impostas a Domingas e Nael. Porém, tudo depende do que se privilegia na leitura e, além disso, do que a obra deixa mais evidente para que seja interpretado.

Por isso que em sua tese sobre os narradores de Milton Hatoum, ao julgar a suposta superficialidade de Lavo, narrador-autor de Cinzas do Norte, em comparação aos romances anteriores, Daniela Birman afirmará que, ao invés de ir fundo em seu passado, como fizeram os do Relato de um certo Oriente e Dois irmãos, "Lavo não enfrenta o próprio lugar no qual se encontra, mergulhando na brecha existente entre os dois discursos e conjuntos de valores e questionando-os" (2007, p. 255). Apesar de vir acompanhada de um julgamento de valor negativo, que imputa a Lavo e ao romance de 2005 mais limitações que aos narradores e aos romances anteriores de Hatoum, a análise não deixa de estar correta, embora o julgamento possa estar equivocado. Pois, ao se observar atentamente o conjunto de Cinzas do Norte, percebe-se que o seu objetivo, diferentemente dos romances anteriores, não é necessariamente o de buscar entender o lugar da memória na narrativa e o modo como a sua recuperação pode questionar posições 
subjetivas e identidades, aspectos que Birman aponta e valoriza no Relato de um certo Oriente e em Dois irmãos. Da mesma forma, o que está em questão não é nem o indivíduo nem o mito. A recordação aqui, parece-me, tem a ver principalmente com o que Süssekind criticou, naquele texto de 1989, como literatura de confissão ou retrato de geração, que é o que Hatoum não fazia no Relato, pelo que ela o valorizava. Agora, contudo, o autor parece estar olhando para trás, os anos 60 no Brasil, e as Cinzas do Norte, mais do que a briga de um pai com um filho, seriam, no fundo, uma representação do fracasso brasileiro. É o que a minha leitura da obra tentará apontar.

Para início de conversa, diria que Milton Hatoum não está sozinho nessa tentativa de produzir romances que têm como pano de fundo a nossa história recente, de entender os processos que vêm contribuindo para formar o Brasil de hoje. Não é o que fez Paulo Lins, em Cidade de Deus? Ou o que está fazendo Luiz Ruffato com a sua pentalogia, os cinco romances de o Inferno provisório? É claro que, à diferença desses, o foco narrativo intimista e, de certo modo, sentimental, o espaço narrativo concentrado sobretudo em Manaus, num tempo mais ou menos preciso, além da contenção estilística, não permitem ver relações assim tão diretas. Por outro lado, são prova da virada estético-literária de Hatoum as palavras do próprio autor, em entrevista à Folha de S. Paulo, quando do lançamento desse romance:

Cinzas do Norte é uma espécie de educação sentimental. É meu livro mais flaubertiano nesse sentido. É um romance da desilusão, sobretudo. Não sobra nada. É, de longe, a coisa mais amarga que eu já escrevi. Tudo termina em cinzas: a cidade, as vidas, os personagens. É um romance da dissipação, dessas vidas que se esvaem. Tudo conflui para o trágico. Salvo a literatura.

Seria gratuita, aqui, a referência à Educação sentimental e a seu autor, Gustave Flaubert? Veja-se então outra referência ao parentesco dos livros, na orelha a Cinzas do Norte, escrita por Samuel Titan Jr., parceiro de Hatoum na tradução de Três contos, do escritor francês. Segundo Titan Jr., "com Cinzas do Norte, Hatoum expande e aprofunda seu projeto ficcional, levando a sério e a cabo a injunção flaubertiana de escrever a 'história moral de sua geração"”.

De fato, em uma primeira visada, não se teria dificuldade em ver similaridade entre Mundo, o artista adolescente, e Frédéric, o protagonista também adolescente do romance de Flaubert. Ambos recusam a herança familiar, são herdeiros falhados, ou nas palavras de Bourdieu (2002), condenados à indeterminação, recusando-se a entrar no mundo dos homens sérios. Frédéric, contudo, é mais radical, interessa-se por tudo, mas não se 
apega a nada, perambula de espaço em espaço, sem desejo de relações com a terra natal, a não ser quando precisa de algum dinheiro que venha de lá para continuar vivendo em Paris. Já Mundo, apesar do apelido, tem o pai e a terra natal como horizonte de tudo o que constrói. A única deriva de Mundo se dá, aparentemente, em termos de sua arte, pois vaga entre a arte política (na adolescência em Manaus), a arte experimental (na sua temporada no exterior) e a arte biográfica e confessional (quando retorna ao Brasil, já doente). De resto, embora negue a herança material e simbólica do pai, passa a sua curta existência combatendo o seu pai e a herança, não se sabe se por motivos políticos ou afetivos, talvez por ambos. De modo que, mesmo que Frédéric também se encontre no meio de uma revolução (a de 1848), a de Mundo é bem mais sentida e não lhe é indiferente. Assim, apesar da homologia entre as personagens, ao que se poderia adicionar o fato de ambos manterem relações complicadas com suas mães, criaturas que exercem poder sobre eles, Mundo, diferentemente de Frédéric, adere a uma perspectiva por assim dizer socialista ou ao menos de crítica social, fixando-se até a sua morte na figura paterna, que lhe resiste.

De sua parte, o amigo de Mundo, Lavo, lembra Deslauries, o amigo de infância de Frédéric, também com poucos meios materiais, e que busca, pelo seu passado sem herança, uma posição estável no mundo profissional. Ou seja, Lavo, apesar de órfão de pai e mãe, deseja ingressar para o rol dos homens sérios, já que ignora os conselhos do seu tio Ranulfo, identificado com Mundo, de abandonar os manuais de direitos e os códigos de leis e se dedicar à literatura. Sem conseguir ousar, Lavo no máximo admira Mundo, a quem observa à distância, assim como Deslauries admira e inveja Frédéric. Por outro lado, não ousa desafiar Jano, a quem teme e a quem eventualmente presta favores, mesmo que se negue a receber por isso. De modo que, como Deslauries, a vida de Lavo é medíocre e, como aquele, acaba se dedicando à advocacia, como se isso fosse lhe garantir a felicidade. A diferença, e que não é pouca, entre as duas personagens, é que Lavo conserva uma ponta de arrependimento e culpa, por não ter ficado do lado de Mundo quando este precisou dele, e ao final decide não herdar, isto é, decide não construir uma carreira, como Deslauries, que inclusive se casa com a namorada de província de Frédéric. Ao contrário daquele, Lavo transforma-se em um escritor. Segue, ao final, o conselho do tio, um meio pelo qual pode dirimir a culpa da impossibilidade de optar entre a revolta e a obediência, entre Mundo e Jano. Ao utilizar um narrador-testemunha, ao invés do narrador onisciente de Flaubert, Hatoum particulariza o que seria apenas um tipo flaubertiano, um personagem que entra e sai do romance para servir de contraponto ao protagonista na descrição da vida social parisiense. Não que ele, Lavo, não seja um pouco isso também, mas à medida em que se trabalha com dois pla- 
nos - o da narração e o do narrado - é impossível não perceber na narrativa que Lavo arma, com a ajuda da história de Ranulfo e das cartas de Mundo, uma forma de denúncia de si e dos outros, em dois momentos específicos da nossa história recente.

Pois se Jano pode ser lido como uma representação da associação dos militares com a burguesia nacional, e Mundo como uma representação dos que se revoltaram contra aquela, a ponto de perder a vida, Lavo, que será no futuro um advogado que defenderá os pobres, parece se referir, no plano do narrado, à classe média alienada ou, mais ainda, aos intelectuais que sabiam o que estava acontecendo e não se posicionaram. Em um momento da narrativa isso fica bem claro, e o padrão se repetirá em outras ocasiões: em uma das primeiras cenas do romance, Jano tenta subornar Lavo para que este afaste Mundo de Arana, o artista da ilha, que ao final do romance se descobrirá que é o pai biológico de Mundo. Lavo não aceita o dinheiro. Por outro lado, logo após a cena do suborno, Lavo seguirá Mundo até o ateliê de Arana, criticando-o aberta e insistentemente para o amigo, em diversos momentos da história, como que a seguir as ordens de Jano.

Assim, o plano da narração, cujo tempo é o de abertura política dos anos de 1980, opera seja como denúncia tardia das atitudes conservadoras de Jano e sua turma, seja como um modo de Lavo expiar a sua culpa e sua fraqueza enquanto indivíduo e/ou intelectual que não agiu, em um momento crucial para o país.

Talvez por dizer tanto do particular, e trazer algumas personagens de certo modo esquemáticas, Cinzas do Norte, mesmo ganhando o prêmio Jabuti, não recebeu tantas resenhas elogiosas de críticos consagrados, ao contrário da novela seguinte, elogiada outra vez, na primeira hora, por Luiz Costa Lima, prova de que o que parece estar em jogo hoje, na recepção positiva de uma narrativa por boa parte da crítica literária brasileira, é sobretudo a sua ambição universal, que Hatoum soube retomar em sua novela de $2008 .^{6}$ Arrisco, assim, uma interpretação da novela, tendo agora em vista o conjunto da obra do autor.

\footnotetext{
${ }^{6}$ Em artigo sobre a recepção mais recente da obra de Machado de Assis, Roberto Schwarz detectou duas tendências críticas, a saber, uma a que ele próprio se vincula e que "[...] busca identificar nela [na obra de Machado] os pontos de liga entre a invenção artística, as tendências internacionais dominantes e as constelações sociais e culturais do atraso, com as sinergias correspondentes" (2012, p. 18), e outra dita cosmopolita ou neouniversalista, “[...] que corta o afluxo das conotações históricas, ou seja, das energias do contexto" (2012, p. 20), para elevar Machado ao cânon da literatura universal. Em boa medida, seriam essas as duas variantes principais que estou buscando detectar também na leitura da obra de Hatoum, com suas nuances próprias, é claro. Embora rivais, não se pode dizer, como no caso de Machado de Assis, que haja uma competição entre elas. Adicionaria, ainda, uma terceira tendência crítica, próxima dos cultural studies, que procura evidenciar o hibridismo dos textos de Hatoum, com base mais nos temas e no espaço manauara, e menos na forma literária.
} 
5. Em termos gerais, o enredo de Órfãos do Eldorado é o do encontro amoroso de Arminto - filho problemático de Amando Cordovil, chefe político e homem de posses de uma pequena localidade na Amazônia chamada Vila Bela - com Dinaura, uma índia órfã, enigmática como a Capitu de Machado de Assis, acolhida pelas irmãs carmelitas do lugar. O narrador da história é o próprio Arminto, já velho, que a teria contado ao avô do escritor, embaixo de uma árvore, à maneira de Iracema.

O relato inicia com Arminto, já adolescente, sendo expulso de casa por Amando após ser flagrado em relação sexual com Florita, agregada da família, responsável por cuidar da casa, e, também, serva sexual de Amando. Detalhe importante, Florita também cuidara de Arminto a vida toda, fora sua mãe postiça, substituta da mãe verdadeira após a morte desta no parto do narrador. E se Amando já culpava Arminto pela morte da mulher, no momento em que este busca tirar dele também a sua "segunda mulher" acaba sendo enxotado de casa. Vê-se que a questão edípica, assim como em Cinzas do norte, acaba fundando o conflito entre pai e filho. Então, Arminto tentará a vida em Manaus, apostará na carreira de advogado com o fito de se aproximar do pai que o rejeita. Diferentemente do romance anterior, é o pai quem rejeita o filho. De todo o modo, antes da reviravolta da narrativa, Amando concordará em conversar com Arminto, na mansão de Vila Bela, numa véspera de Natal, vislumbrando-se, quem sabe, uma reconciliação de ambos. Mas, ao se encontrarem, Amando tem uma síncope e morre. E é justamente no enterro do pai que Arminto conhecerá Dinaura, "a mulher de duas idades", por quem abandonará todos os sonhos do pai e assumirá os seus próprios, resumidos na sua busca pelo Eldorado pessoal, encarnado nos olhos ambíguos de Dinaura.

Daí em diante, a partir desse primeiro encontro, se iniciará também a decadência material de Arminto - inábil para lidar com a vida prática consolidada com o naufrágio do Eldorado, principal navio da empresa paterna que o narrador herdara. Por outro lado, concomitantemente, iniciará também o projeto individual do protagonista de reencontrar o paraíso perdido. Porque, depois da única noite de amor com Arminto, Dinaura desaparecerá de Vila Bela. E toda a sua existência, desde o dia em que a conheceu, será dedicada a ela, ou melhor, à lembrança dela, aquela que portava no olhar voraz o mais íntimo do narrador. Frente a seu Eldorado, nada mais importará, e os seus últimos dias ele passará em uma tapera, sem dinheiro, comendo graças ao favor do outros.

$\mathrm{Na}$ parte final da novela, procurado por Estiliano - advogado da empresa e melhor amigo do seu pai - que está em vias de morrer, Arminto saberá algo mais sobre Dinaura. Saberá que ela foi se isolar em uma ilha chamada justamente Eldorado, que morava numa casa atrás do convento das 
carmelitas, com despesas pagas por Amando, que poderia ter sido mulher ou filha deste, que sabia que a história deles não era possível, e que teria sumido ou por causa disso ou por alguma doença. Da última viagem de Arminto ao Eldorado, em busca de Dinaura, é impossível inferir o que encontrou, haja vista o seu relato sintético ao adentrar uma das casas habitadas da ilha:

Era a única coberta de telhas, com uma varanda protegida por treliça de madeira e uma lata com bromélias ao lado da escadinha. Um ruído no lugar. Na porta vi o rosto de uma moça e fui sozinho ao encontro dela. Escondeu o corpo, e eu perguntei se morava ali. Moro com minha mãe, ela disse, esticando o beiço para o outro lado do lago.

Onde estão os outros?

Morreram e foram embora.

Morreram e foram embora?

Ela confirmou. E apareceu aos poucos, até mostrar o corpo inteiro, retraído pela timidez e desconfiança.

Trabalhava nesta casa?

Passo o dia aqui.

Conhecia uma mulher... Dinaura?

Recuou um pouco, juntou as mãos, como se rezasse, e virou a cabeça para o interior da casa.

A sala era pequena, com poucos objetos: uma mesinha, dois tamboretes, uma estante baixa, cheia de livros. Duas janelas abertas para o lago do Eldorado. Parei perto do corredor estreito. Antes de eu entrar no quarto, o prático e a moça me olhavam, sem entender o que estava acontecendo, o que ia acontecer. (HATOUM, 2008, p. 102-103).

No fundo, para o conjunto da narrativa, pouco importa o que Arminto encontrou no lugar, "o que estava acontecendo, o que ia acontecer", uma vez que ele já havia descoberto, no velório do pai, algo bem mais valioso, a saber, a sua singularidade, o seu Eldorado, e passara boa parte da sua existência ao redor disso.

Portanto, se de um lado julga-se que o narrador perdeu toda a sua fortuna por causa de Dinaura, lendo a obra como uma tragédia, de outro, ao se colocar na posição de Arminto, daquele que nega um projeto que não é dele, sugere-se que, movido pelo desejo, ele coloca em xeque a lógica ordenadora e repetitiva do pai e do autoritarismo brasileiro, figurada na personagem de Amando Cordovil. Porque a partir do momento em que conhece Dinaura, Arminto abandona o passado, a tradição que não fora por ele instituída, mas que imaginava, graças à crença no Outro, que daria algum sentido a sua vida. Dito de outro modo, a partir do momento em que se apaixona por Dinaura, Arminto encontra a busca pelo seu objeto de desejo - o que lhe é 
mais distante e ao mesmo tempo mais próximo, além de irremediavelmente seu e para sempre perdido. Recordando a sua última viagem, rumo à ilha, numa parada em Manaus, ele declara ao seu interlocutor:

No cais, fui cercado por vendedores de objetos deixados pelos americanos durante a Segunda Guerra. Não comprei nada. Ninguém reconheceu um Cordovil do passado. Eu até podia estar na pele de um dos marreteiros; a diferença é que minha história era outra. Mas isso não é tudo? Por vingança e por prazer pueril eu tinha jogado fora uma fortuna. E olha só: não me arrependo. (HATOUM, 2008, p.100-101).

A "vingança", ou talvez a escolha, de Arminto se efetiva não pela competição com o pai, como se deu no caso de Mundo, ou por meio da construção de um império maior do que o dele, mas via "prazer pueril", de rejeição radical dos valores paternos, de que o narrador, aliás, não se arrepende. Assim, Arminto está muito mais próximo do que Mundo das derivas de Frédéric e da sua disposição de não levar a sério qualquer projeto que lhe seja imposto. o único projeto de Frédéric, vale frisar, seria aquele que vinculava amor e arte, encarnado na Sra. Arnoux. E caso se siga com o paralelo, pode-se aventar que não é o amor pela arte que está nos planos de Arminto, mas a inalcançável arte do amor de Dinaura, o que, no fim das contas, dá quase no mesmo, já que ambos os investimentos implicam na recusa da vida burguesa. Nos termos de Bourdieu, cuja análise da obra de Flaubert pode servir de parâmetro neste caso,

A tendência do patrimônio (e, por aí, de toda a estrutura social) em perseverar em seu ser apenas pode realizar-se se a herança herda o herdeiro, se, por intermédio especialmente daqueles que lhe têm provisoriamente o encargo e que devem assegurar sua sucessão, 'o morto (ou seja, a propriedade) apossa-se do vivo (ou seja, um proprietário disposto a herdar)'. (BOURDIEU, 2002, p. 26).

6. Havia mencionado na introdução deste ensaio que Hatoum, com Órfãos do Eldorado, retornava ao projeto inicial do Relato de um certo Oriente, na sua busca por uma literatura de corte mais universal. De fato, em termos da construção das personagens, o autor, cujo alter-ego pode ser Arminto, tenta se desvencilhar dos traços realistas, locais, da tradição de uma literatura empenhada, que marcaram a escrita e a recepção de Cinzas do Norte. Daí a importância, de um lado, como assinalou Luiz Costa Lima (2008) em resenha 
à obra, de uma leitura múltipla do mito do Eldorado, seguida da forma curta e elíptica da novela; e de outro, a meu ver, da própria fábula, da história que se lê, a qual permite, ao final, uma homologia entre Arte, Eldorado e Dinaura, duplicadas por sua vez na janela da capa da edição brasileira: espaço de invenção, limiar que se deve transgredir para se enxergar mais longe.

\section{REFERÊNCIAS}

ANDRADE, Fábio de Souza. Os despojos da revolta. Ilustrada, Folha de S. Paulo, São Paulo. p. $2.17 / 09 / 2005$.

BIRMAN, Daniela. Entre-narrar: relatos da fronteira em Milton Hatoum. Tese (Doutorado em Literatura Comparada) - Programa de Pós-Graduação em Ciência da Literatura, Faculdade de Letras. 290 f. Universidade Federal do Rio de Janeiro, Rio de Janeiro, 2007.

BOURDIEU, Pierre. As regras da arte: gênese e estrutura do campo literário. São Paulo: Companhia das Letras, 2002.

BOSI, Alfredo. História concisa da literatura brasileira. São Paulo: Cultrix, 2003.

FISCHER, Luiz Augusto. Um narrador, dois irmãos e o retrato do povo brasileiro. Folhateen, Folha de S. Paulo, São Paulo, p. 10. 23/10/2000.

HATOUM, Milton. Relato de um certo Oriente. São Paulo: Companhia das Letras, 1989.

Dois irmãos. São Paulo: Companhia das Letras, 2000.

. Cinzas do Norte. São Paulo: Companhia das Letras, 2005.

Órfãos do Eldorado. São Paulo: Companhia das Letras, 2008.

LIMA, Luiz Costa. A ilha flutuante. Mais!, Folha de S. Paulo, São Paulo, p. 18-19. 24/09/2000. . Intervenções. São Paulo: Edusp, 2002.

. Naufrágio da tradição. Mais!, Folha de S. Paulo, São Paulo, p. 8. 06/04/2008.

NUNES, Benedito. A volta ao mito na ficção brasileira. Cronos, Natal, v. 7, n. 2, p. 333-337, 2006.

PELEGRINI, Tania. Milton Hatoum e o regionalismo revisitado. Luso-Brazilian Review, Wisconsin, v. 41, n. 1, p. 121-138, 2004.

PERRONE-MOISÉS, Leyla. Altas literaturas: escolha e valor na obra crítica de escritores modernos. São Paulo: Companhias das Letras, 1998.

.A cidade flutuante. Jornal de Resenhas, Folha de S. Paulo, São Paulo, p. 7. 12/08/2000.

SCHWARZ, Roberto. Martinha versus Lucrécia: ensaios e entrevistas. São Paulo: Companhia das Letras, 2012.

STAIGER, Emil. Conceitos fundamentais da poética. Tempo Brasileiro: Rio de Janeiro, 1975.

SÜSSEKIND, Flora. Livro de Hatoum lembra jogo de paciência. Letras, Folha de S. Paulo, São Paulo, p. 6. 29/04/1989.

Submetido em: 03/12/2011

Aceito em: 26/01/2013 